\title{
ANALIZA ROZWOJU RYNKU TELEFONII MOBILNEJ W POLSCE W LATACH 2002-2013
}

\section{Wprowadzenie}

Jeszcze w latach 80. w krajach Wspólnoty Europejskiej i na świecie rynki telekomunikacyjne miały formę monopoli naturalnych. Na rynkach tych działali operatorzy - monopoliści, których majątek stanowił najczęściej własność państwa. Taki sposób funkcjonowania rynków telekomunikacyjnych wynikał z przekonania o wysokich kosztach wejścia na rynek i kosztach stałych związanych z działalnością operatorską. Stan rozwoju techniki i technologii w dziedzinie telekomunikacji uniemożliwiał świadczenie usług łączności elektronicznej przy znaczącym obniżeniu tych kosztów.

Idea świadczenia usług telekomunikacyjnych w formie rynku opartego na konkurencji pojawiała się już na początku XX w. Dopiero osiągnięcia techniczne i technologiczne pozwoliły na świadczenie tych usług bez potrzeby korzystania z dotychczasowej infrastruktury sieciowej np. poprzez sieci GSM lub telewizję kablową. Inicjowanie konkurencji na rynkach telekomunikacyjnych odbywało się pod ochroną odpowiednich organów regulacyjnych (regulatorów). Najwcześniej pełna demonopolizacja sektora usług łączności elektronicznej nastąpiła w USA ${ }^{1}$.

W celu liberalizacji i harmonizacji unijnego rynku telekomunikacyjnego podjęto działania, których początkowym efektem była Zielona księga z 1987 r. W wyniku jej wydania Komisja Europejska skoncentrowała się na: szybkim i pełnym otwarciu rynku telekomunikacyjnego urządzeń końcowych dla konkurencji, oddzieleniu funkcji regulacyjnych i operatorskich, ustaleniu warunków dostępu do sieci i usług poprzez wprowadzenie pojęcia otwartego dostępu do sieci i usług (open network provision, ONP) i rozwoju standaryzacji przez utworzenie Europejskiego Instytutu Standardów Telekomunikacyjnych (European Telecommunications Standards Institute,

1 Proces demonopolizacji telekomunikacji w USA jest szczegółowo opisany w: B. Borkowska, Monopolizacja i demonopolizacja rynku telekomunikacji w USA, w: Mikroekonomia. Studia przypadków, red. B. Klimczak, A. Matysiak, Wydawnictwo AE im. Oskara Langego we Wrocławiu, Wrocław 2006, s. 107-117. 
ETSI). Zielone księgi wydano jeszcze w latach 1993-2002. Dotyczyły one komunikacji ruchomej i osobistej, infrastruktury telekomunikacyjnej oraz sieci kablowych. Na szczycie w Lizbonie w 2000 r. przyjęto założenia i cele tzw. strategii lizbońskiej. Dalsza liberalizacja telekomunikacji, ale również energetyki i transportu miała doprowadzić do urzeczywistnienia celu przewodniego, czyli osiągnięcia wysokiej konkurencyjności gospodarki europejskiej².

Celem niniejszego opracowania jest zatem analiza i ocena rozwoju polskiego rynku telekomunikacyjnego w zakresie telefonii mobilnej. Dyskusją objęto uwarunkowania prawne, techniczne i technologiczne przekształceń modeli rynkowych w analizowanym zakresie na tle pozostałych segmentów rynku łączności elektronicznej: telefonicznych połączeń lokalnych, telefonicznych połączeń międzystrefowych, międzynarodowych i do sieci mobilnych oraz dostępu do internetu.

Postawiono tezę, że na polskim rynku telefonii mobilnej w latach 2002-2013 nastąpił wielokrotny wzrost popytu na usługi połączeniowe. Dyskusję uzupełniono więc o wskaźniki liczbowe świadczące o dynamice ilościowej, wielkości i znaczeniu badanego segmentu polskiego rynku telekomunikacyjnego.

\section{Uwarunkowania przekształceń rynkowych w segmencie telefonii mobilnej na tle pozostałych segmentów sektora telekomunikacyjnego}

Wyjściową formą rynku telekomunikacyjnego w Polsce (podobnie jak w innych krajach) był monopol. Monopolistą była Telekomunikacja Polska SA. Polskie aspiracje dotyczące akcesji europejskiej wiązały się jednak w zakresie analizowanego rynku z przeprowadzeniem procesu demonopolizacji i liberalizacji, a także z powołaniem niezależnego regulatora. Zadaniem regulatora miała być kontrola obowiązku wdrażania acquis communautaire w obszarze Telekomunikacja i technologie informacyjne ${ }^{3}$.

2 Kształtowanie konkurencji w sektorze telekomunikacji Unii Europejskiej zostało opisane m.in. w: Z. Wysokińska, Polityka konkurencji Unii Europejskiej na rynkach sektorów sieciowych na przykładzie rynku energetycznego i telekomunikacyjnego, w: Regionalne aspekty polityki konkurencji w procesie integracji europejskiej, red. J. Witkowska, Z. Wysokińska, Wydawnictwo UŁ, Łódź 2006, s. 22-25.

3 Kształtowanie konkurencyjności polskiego rynku telekomunikacyjnego zostało szeroko opisane w: H. Babis, Istota rynku ustug telekomunikacyjnych, w: Rynek ustug telekomunikacyjnych, red. H. Babis, Wolters Kluwer Polska, Warszawa 2011, s. 46-59; A. Budziewicz-Guźlecka, Przekształcenia polskiego rynku telekomunikacyjnego, w: Rynek ustug telekomunikacyjnych, ibidem, s. 102-141; W. Maziarz, Ewolucja rynku ustug telekomunikacyjnych w latach 1987-2007, w: Przeobrażenia na rynku łączności i kierunki jego rozwoju, red. H. Babis, G. Wolska, „Zeszyty Naukowe” nr 463, „Ekonomiczne Problemy Łączności” nr 10, Wydawnictwo USz, Szczecin 2007, s. 269-283; A. Budziewicz-Guźlecka, Liberalizacja polskiego rynku 
Dostosowanie polskiego prawa do wymogów europejskich w perspektywie ostatnich 25 lat skutkowało przeobrażeniami modeli rynkowych w poszczególnych segmentach sektora usług telekomunikacyjnych. Aktem prawnym, który zapoczątkował proces demonopolizacji i liberalizacji rynku telekomunikacyjnego w Polsce, była ustawa z dnia 23 listopada 1990 r. o łączności ${ }^{4}$. Na mocy tej ustawy dotychczasowe przedsiębiorstwo Poczta Polska, Telegraf i Telefon zostało podzielone na przedsiębiorstwo pocztowe i telekomunikacyjne. W związku z tym w grudniu 1991 r. powstała Telekomunikacja Polska SA jako spółka akcyjna Skarbu Państwa. Głównym celem tej ustawy było odejście od monopolu państwa w dziedzinie poczty, telekomunikacji, radiofonii i telewizji (demonopolizacja). Dopuszczono zatem na rynek telekomunikacyjny innych niezależnych operatorów. Przy czym zakres demonopolizacji nie był pełny, tzn. uniemożliwiono konkurencyjnym operatorom świadczenia usług międzynarodowych, a podmiotom zagranicznym oraz ze znacznym udziałem kapitału zagranicznego (powyżej 49\%) również połączeń międzymiastowych. Państwowemu monopoliście pozostawiono zatem wyłączność na najbardziej dochodowe usługi telekomunikacyjne.

Liberalizacja polskiego rynku telekomunikacyjnego została pogłębiona poprzez nowelizację $e^{5}$ ustawy o łączności z dnia 12 maja $1995 \mathrm{r}$. Wprowadzono bardziej przejrzysty system udzielania uprawnień do prowadzenia działalności telekomunikacyjnej. Dotychczasowe zezwolenia zostały zastąpione płatnymi koncesjami na świadczenie usług telefonicznych i zezwoleniami na zakładanie i używanie sieci telekomunikacyjnej. Oczekiwano, że w ten sposób wyłonieni zostaną operatorzy, którzy na obszarach, na których dotychczas nie działał żaden niezależny operator lokalny, wybudują sieć telefoniczną i przyłączą do niej abonentów. Wskutek nowelizacji ustawy minister łączności w latach 1995-2000 udzielił łącznie ponad 600 zezwoleń i koncesji na prowadzenie działalności telekomunikacyjnej dla operatorów, service providerów (ISP) dostępu do internetu oraz innych operatorów. W segmencie połączeń lokalnych monopol został zastąpiony przez duopol, tzn. na terenie każdego z byłych województw (w tej samej strefie numeracyjnej) udzielano koncesji tylko jednemu alternatywnemu operatorowi. W segmencie połączeń międzymiastowych i międzynarodowych nadal istniał monopol. Natomiast wyraźnym sukcesem w tym czasie było utworzenie oligopolu w zakresie telefonii mobilnej. Na rynku tym pojawiło się trzech operatorów posiadających własną infrastrukturę telekomunikacyjną (mobile

telekomunikacyjnego jako efekt uregulowań prawnych, w: Przeobrażenia na rynku łączności i kierunki jego rozwoju, ibidem, s. 303-313; M. Raczyński, Reformy sektora telekomunikacji w Polsce, w: Regulacyjna rola państwa we współczesnej gospodarce, red. D. Kopycińska, Print Grup, Szczecin 2006, s. 297-303.

4 DzU nr 86, poz. 504, z późn. zm.

5 DzU nr 60, poz. 310. 
network operator, MNO). Byli to wówczas operatorzy: PTC Sp. z o.o., PTK Centertel Sp. z o.o. oraz Polkomtel SA, z których każdy opanował prawie równe udziały w przychodach 6 . W segmencie usług dostępu do internetu zaistniała konkurencja monopolistyczna z przewagą TP SA.

Kolejnym ważnym aktem (dalej liberalizującym działalność telekomunikacyjną) była ustawa z dnia 21 lipca 2000 r. - Prawo telekomunikacyjne ${ }^{7}$. Bodźcem do przyjęcia tej ustawy była dyrektywa Unii Europejskiej 97/33/WE, która zakładała powołanie niezależnego organu regulacji telekomunikacji, ustalenie nowej polityki cenowej oraz uregulowanie obszaru usług powszechnych. Prawo telekomunikacyjne było aktem prawnym, który powołał nowy organ regulacyjny - Urząd Regulacji Telekomunikacji (URT) ${ }^{8}$. Urząd ten otrzymał szerokie uprawnienia nadzorcze, kontrolne i władcze w stosunku do uczestników rynku (np. zasady ustalania cen usług telekomunikacyjnych, kształtowanie warunków współpracy pomiędzy operatorami). $\mathrm{Na}$ mocy tej ustawy odstąpiono od koncesjonowania działalności telekomunikacyjnej. Uzyskanie zezwolenia konieczne było na eksploatację publicznej sieci telefonicznej stacjonarnej i ruchomej oraz sieci służących do rozpowszechniania i rozprowadzania programów radiofonicznych i telewizyjnych. Relatywnie do uprzednich koncesji, które niejednokrotnie stanowiły problem dla alternatywnych operatorów, obniżono opłaty za zezwolenia (w najwyższym przedziale 5000 euro). Rozpoczęcie pozostałej działalności telekomunikacyjnej wymagało jedynie jej zgłoszenia do Prezesa URT. Istotną zmianą zbliżającą prawo polskie do unijnego było zobowiązanie podmiotów o znaczącej pozycji rynkowej do dzierżawy swoich łączy każdemu zainteresowanemu podmiotowi. Ponadto cena dzierżawy zależała jedynie od realnego kosztu usługi dzierżawy, a dla standaryzacji i przejrzystości umów zobowiązano podmioty do przygotowania ramowej oferty zawierającej warunki zawarcia umowy dzierżawy. Celem tej ustawy było wspieranie równoprawnej i skutecznej konkurencji w zakresie świadczenia usług telekomunikacyjnych oraz zapewnienie użytkownikom maksymalnych korzyści w zakresie różnorodności, ceny i jakości usług telekomunikacyjnych. W komentowanej ustawie zaplanowano pełną liberalizację rynku usług

6 Wśród opracowań poświęconych rozwojowi rynku telefonii mobilnej znajdują się: J. Bryła, Konkurencja cenowa telefonii komórkowej na rynku polskim na tle rynku światowego, w: Funkcjonowanie i rozwój korporacji wielonarodowych $w$ wybranych sektorach uslugowych i produkcyjnych, cz.1, red. J. Kubicka, Wydawnictwo Wyższej Szkoły Biznesu w Dąbrowie Górniczej, Dąbrowa Górnicza 2008, s. 131-170; M. Duszak, B. Bartoszewska, M. Olender-Skorek, Obraz polskiego rynku telefonii mobilnej w świetle postępującej konkurencyjności rynku, w: Przeobrażenia na rynku łączności i kierunki jego rozwoju, op.cit., s. 315-324.

$7 \mathrm{DzU}$ nr 73, poz. 852, z późn. zm.

8 W kwietniu 2002 r. URT został przekształcony w Urząd Regulacji Telekomunikacji i Poczty (URTiP) na mocy ustawy z dnia 1 marca 2002 r. o zmianie w organizacji i funkcjonowaniu centralnych organów administracji rządowej i jednostek im podporządkowanych, DzU nr 25, poz. 253. 
międzymiastowych i lokalnych od początku 2002 r. oraz połączeń międzynarodowych od 2003 r. Określono zasady przenoszenia numerów klientów zmieniających dostawcę. Szerzej zdefiniowano również pakiet tzw. usług powszechnych, do których dostęp przysługiwał abonentom z całego kraju. Należały do nich m.in. usługi telefoniczne, transmisja faksów i dostęp do internetu przez modem.

Prawo telekomunikacyjne zostało następnie zmienione przez dwie nowelizacje ${ }^{9}$, tj. z dnia 22 maja 2003 r. oraz 16 lipca 2004 r. Celem nowego prawa w zakresie telekomunikacji było zagwarantowanie powszechnej, tańszej i szybszej łączności telekomunikacyjnej. Przyjęte zmiany były konieczne ze względu na to, że w krajach Unii Europejskiej w dniu 25 lipca 2003 r. weszły w życie przepisy zmieniające regulację rynku telekomunikacyjnego. Do ważniejszych zapisów pierwszej nowelizacji ustawy należało: sformułowanie uregulowań dotyczących kompatybilności elektromagnetycznej oraz wprowadzenie sprawniejszej regulacji i szerszej konsultacji regulatora w zakresie projektów rozwiązań mających istotny wpływ na rynek telekomunikacyjny (np. współkorzystania z infrastruktury telekomunikacyjnej, przenoszenia numerów czy ochrony konsumenta, w tym także przejrzystości taryf oraz warunków rozstrzygania sporów). Ustawa była kolejnym krokiem dostosowującym prawo polskie do unijnego. Jednak liberalizacja rynku w telekomunikacji miała miejsce przede wszystkim w segmencie usług telefonii komórkowej i dostępu do internetu. Natomiast ustawa z dnia 16 lipca 2004 r. - Prawo telekomunikacyjne zawierała zapisy, które zakładały odejście od sztywnej regulacji rynku telekomunikacyjnego i przejście do regulacji uwzględniającej rzeczywiste warunki i potrzeby rynkowe (wprowadzanie mechanizmu regulacyjnego tam, gdzie prawo konkurencji jest niewystarczające) oraz wiele nowych możliwości i zadań dla regulatora (administracyjne nakładanie obowiązków, procedura regulacji ex ante, postępowanie konsultacyjne, konsolidacyjne i mediacyjne, analiza konkurencji na osiemnastu rynkach telekomunikacyjnych). Działania regulatora mają wzmacniać konkurencję w zakresie dostarczania sieci telekomunikacyjnych oraz wspierać rozwój rynku wewnętrznego w sektorze telekomunikacji i, co za tym idzie, zapewnić użytkownikom maksymalne korzyści w zakresie szerokiej oferty usług, ceny oraz jakości usług telekomunikacyjnych. W wyniku zmian w otoczeniu prawnym w 2004 r. zarówno na rynku połączeń lokalnych, jak i rynku połączeń międzymiastowych i międzynarodowych miała miejsce konkurencja monopolistyczna $\mathrm{z}$ dominującym udziałem TP SA. Takim samym modelem rynkowym charakteryzował się segment dostępu do internetu. Natomiast rynek telefonii ruchomej nadal miał charakter oligopolu. Wprowadzenie zasad konkurencji w obszarze usług telefonii mobilnej i dostępu do internetu było łatwiejsze pod względem technicznym

9 DzU nr 113, poz. 1070; DzU nr 171, poz. 1800, z późn. zm. 
i prawnym, ponieważ rynek dopiero się kształtował. Uwolnienie rynku usług w segmencie telefonii stacjonarnej było znacznie trudniejsze ze względu na problemy budowy potrzebnej i kosztownej infrastruktury.

Od 14 stycznia 2006r. rolę regulatora pełni Prezes Urzędu Komunikacji Elektronicznej (UKE). Urząd ten został powołany (w miejsce zlikwidowanego URTiP) na mocy ustawy z dnia 29 grudnia 2005 r. o przekształceniach i zmianach w podziale zadań i kompetencji organów państwowych właściwych w sprawach łączności, radiofonii i telewizji ${ }^{10}$. Dzięki rozszerzeniu możliwości regulatora i jego wzmożonej aktywności od 2006 r. proces liberalizacji rynku stał się bardziej efektywny. TP SA jednak nadal utrzymywała znaczącą przewagę konkurencyjną ${ }^{11}$. Do ważniejszych rozwiązań UKE stymulujących zachowania konkurencyjne w zakresie rynku telefonii mobilnej należy zaliczyć: umożliwienie rozpoczęcia działalności podmiotom bez własnej infrastruktury (mobile virtual network operator, MVNO) poprzez utworzenie hurtowego rynku usług głosowych w sieciach ruchomych (MVNO Voice), udostępnienie częstotliwości radiowych podmiotom spoza segmentu telefonii mobilnej doprowadzające do wejścia na rynek komórkowy trzech nowych graczy (Netia Mobile obecnie P4, Centernet i Mobiland) i w efekcie do wzrostu różnorodności usług i spadku cen, regulacje (obniżki) stawek międzyoperatorskich na połączenia kończące się w sieciach ruchomych (mobile termination rate, MTR), umożliwienie przenoszenia numeru przy zmianie operatora, gwarantujące transfer numeru w terminie jednego dnia.

Prawo telekomunikacyjne było jeszcze czterokrotnie nowelizowane. Nowelizacje $^{12} \mathrm{z}$ dnia 29 kwietnia 2010 r., 15 kwietnia 2011 r., 16 września 2011 r. oraz 16 listopada 2012 r. doprowadziły do jej pełnej spójności z przepisami prawa unijnego. Jego podstawowymi założeniami są: stworzenie silnej konkurencji na rynku, dostarczenie podstaw do poprawy jakości i rozwoju nowoczesnych usług telekomunikacyjnych, zapewnienie mechanizmów warunkujących dalszy rozwój konkurencji na rynku (stwarzając użytkownikom możliwość wyboru i dostępu do nowoczesnych usług teleinformatycznych), zagwarantowanie powszechnej dostępności usług telekomunikacyjnych (równoważenie taryf i kosztowa orientacja cen), zapewnienie środków regulujących

10 DzU nr 267, poz. 2258, z późn. zm.

11 Wśród publikacji wskazujących na dominującą pozycję TP SA w początkowych latach istnienia UKE znajdują się m.in.: Informacja o wynikach kontroli realizowania przez Prezesa Urzędu Komunikacji Elektronicznej zadań w zakresie regulacji rynku usług telekomunikacyjnych, NIK, Departament Komunikacji i Systemów Transportowych, Warszawa 2008, s. 19-21; B. Bartoszewska, M. Duszak, M. Olender-Skorek, Przewaga konkurencyjna firmy na przykładzie TP SA, w: Przeobrażenia na rynku łączności i kierunki jego rozwoju, op.cit., s. 485-492; J. Kubasik, Batalia o konkurencję w polskiej telekomunikacji, w: Przeobrażenia na rynku łączności i kierunki jego rozwoju, ibidem, s. 285-301.

12 DzU nr 86, poz. 554; DzU nr 102, poz. 587; DzU nr 234, poz. 1390; DzU 2012, poz. 1445. 
i kontrolnych ${ }^{13}$. Modele rynku w poszczególnych segmentach nie uległy większym zmianom, ale dostęp do internetu zaczął być oferowany w ramach bardzo silnej konkurencji ${ }^{14}$. Było to spowodowane inwestycjami w nowe sieci (np. 3G, WiMax) lub efektywnym gospodarowaniem dostępnymi zasobami (np. szybki internet bezprzewodowy CDMA w nieużywanym paśmie $450 \mathrm{MHz}$ ). Wysoki stopień konkurencji potwierdza niska wartość wskaźnika koncentracji rynku $\left(C R_{k}\right)$, w tym również wskaźnika Herfindahla-Hirschmana $(H H I)^{15}$. Są to wskaźniki informujące o stopniu konkurencji w danej branży. Wyższym wartościom wskaźników odpowiadają niższe poziomy konkurencji. Oblicza się je według wzorów:

$$
\begin{gathered}
C R_{k}=\sum_{i=1}^{k} s_{i}, \quad C R_{k} \in[0,100] \\
H H I=10000 \cdot \sum_{i=1}^{k} s_{i}, \quad H H I \in[0,10000]
\end{gathered}
$$

gdzie:

$s_{i}$ - udział w rynku $i$-tej firmy, $i=1, \ldots, k$.

Przekształcenia modeli rynkowych w ramach sektora telekomunikacyjnego przedstawia tabela 1 .

Jeszcze do niedawna w literaturze przedmiotu jako operatorów telekomunikacyjnych, wywierających presję hiperkonkurencyjną w zakresie dostępu do internetu, wskazywano przede wszystkim operatorów telefonii stacjonarnej, a w drugiej kolejności wymieniano operatorów TVK ${ }^{16}$. Obecnie znaczącą pozycję we wspomnianym segmencie zajmują operatorzy telefonii mobilnej. Ich udział pod względem liczby użytkowników wynosi około 40\% i stanowią już konkurencję dla stacjonarnych

13 Wyczerpujący opis Prawa telekomunikacyjnego ze wszystkimi zmianami do grudnia 2012 r. znajduje się w: S. Piątek, Prawo telekomunikacyjne. Komentarz, Wydawnictwo C.H. Beck, Warszawa 2013.

${ }^{14}$ Przekształcenia rynku w segmencie telefonii stacjonarnej i dostępu do internetu wraz z towarzyszącą im dynamiką ilościową podstawowych parametrów rynkowych została opisana w: P. Kaczmarczyk, Dynamika i stan rynku telefonii stacjonarnej w Polsce, „Zeszyty Naukowe Państwowej Wyższej Szkoły Zawodowej w Płocku. Nauki Ekonomiczne" t. XVIII, Płock 2013, s. 54-9; P. Kaczmarczyk, Dynamika ilościowa polskiego rynku telekomunikacyjnego w segmencie dostępu do Internetu w latach 2002-2012, w: Przedsiębiorstwa, banki i regiony w gospodarce, red. nauk. J. Grzywacz, S. Kowalski, Wydawnictwo Państwowej Wyższej Szkoły Zawodowej w Płocku, Płock 2014, s. 211-222.

${ }^{15}$ B. Ciesielski, Wplyw integracji z Uniq Europejska na rozwój konkurencji w polskim sektorze usług telekomunikacyjnych, „Zeszyty Naukowe Wyższej Szkoły Zarządzania” nr 3(53), Wydawnictwo PRET SA, Warszawa 2011, s. 37-40; obliczenia własne.

16 Badania określające rodzaj operatorów telekomunikacyjnych wywierających hiperkonkurencyjną presję w poszczególnych segmentach rynku łączności elektronicznej znajdują się w: A. Małachowski, Hiperkonkurencja operatorów telekomunikacyjnych $w$ Polsce, w: Wspótczesne aspekty informacji, t. 2, red. J. Goliński, K. Krauze, A. Kobyliński, M. Grzywińska-Rąpca, Oficyna Wydawnicza SGH, Warszawa 2010, s. 15-24. 
technologii dostępowych traktowanych łącznie, tzn. oferowanych przez operatorów telefonii stacjonarnej i operatorów TVK.

Tabela 1. Przekształcenia modeli rynkowych w poszczególnych segmentach usług telekomunikacyjnych w Polsce w ostatnim dwudziestopięcioleciu

\begin{tabular}{|c|c|c|c|c|c|}
\hline \multirow[b]{2}{*}{ Rok } & \multicolumn{3}{|c|}{ Telefonia stacjonarna } & \multirow[b]{2}{*}{ Telefonia ruchoma } & \multirow[b]{2}{*}{ Dostęp do internetu } \\
\hline & $\begin{array}{c}\text { telefoniczne } \\
\text { połączenia lokalne }\end{array}$ & \multicolumn{2}{|c|}{$\begin{array}{l}\text { telefoniczne połączenia międzystrefowe, } \\
\text { międzynarodowe i na komórkę }\end{array}$} & & \\
\hline 1990 & monopol & \multicolumn{2}{|l|}{ monopol } & monopol & monopol \\
\hline 1995 & duopol & \multicolumn{2}{|l|}{ monopol } & oligopol & $\begin{array}{l}\text { konkurencja } \\
\text { monopolistyczna }\end{array}$ \\
\hline 2004 & $\begin{array}{l}\text { konkurencja } \\
\text { monopolistyczna } \\
\\
C R_{3}=96 \% \\
\mathrm{HHI}=8474\end{array}$ & $\begin{array}{l}\text { konkurencja } \mathrm{r} \\
\mathrm{MS}^{\mathrm{a}} \\
\mathrm{CR} \mathrm{R}_{3}=94 \% \\
\mathrm{HH}=6481\end{array}$ & $\begin{array}{l}\text { nonopolistyczna } \\
\mathrm{MN}^{\mathrm{b}} \\
\mathrm{CR}{ }_{3}=92 \% \\
\mathrm{HHI}=5613\end{array}$ & $\begin{array}{l}\text { oligopol } \\
\\
C R_{3}=100 \% \\
H H I=3368\end{array}$ & $\begin{array}{l}\text { konkurencja } \\
\text { monopolistyczna } \\
\\
C R_{4}=82 \% \\
\mathrm{HHI}=4536\end{array}$ \\
\hline 2009 & $\begin{array}{l}\text { konkurencja } \\
\text { monopolistyczna } \\
\\
\mathrm{CR}_{3}=92 \% \\
\mathrm{HHI}=6242\end{array}$ & $\begin{array}{l}\text { konkurencja } \mathrm{r} \\
\mathrm{MS}^{\mathrm{a}} \\
\mathrm{CR}_{3}=88 \% \\
\mathrm{HH}=4942\end{array}$ & $\begin{array}{l}\text { nonopolistyczna } \\
\mathrm{MN}^{\mathrm{b}} \\
\mathrm{CR} \mathrm{R}_{3}=76 \% \\
\mathrm{HHI}=4076\end{array}$ & $\begin{array}{l}\text { oligopol } \\
\\
C R_{3}=91 \% \\
H H I=2849\end{array}$ & $\begin{array}{l}\text { konkurencja } \\
\text { monopolistyczna } \\
\\
C R_{4}=61 \% \\
H H I=1348\end{array}$ \\
\hline 2013 & \multicolumn{3}{|c|}{$\begin{array}{l}\text { konkurencja monopolistyczna }^{\mathrm{c}} \\
\mathrm{CR}=77,5 \% \\
\mathrm{HHl}=3060\end{array}$} & $\begin{array}{l}\text { oligopol } \\
\\
C R_{3}=84 \% \\
H H I=2371\end{array}$ & $\begin{array}{l}\text { konkurencja } \\
\text { monopolistyczna } \\
C R_{4}=50 \% \\
H H I=691\end{array}$ \\
\hline
\end{tabular}

${ }^{\mathrm{a}} \mathrm{MS}$ - połączenia międzystrefowe.

${ }^{\mathrm{b}} \mathrm{MN}$ - połączenia międzynarodowe.

${ }^{\mathrm{c}}$ W raporcie UKE za rok 2013 nie uwzględniono wcześniej przyjętego podziału rynku telefonii stacjonarnej.

Źródło: Opracowanie własne na podstawie: P. Szkudlarek, Demonopolizacja rynku usług telekomunikacyjnych w Polsce, w: Rozwój i funkcjonowanie gospodarki, red. Cz. Sułkowski, „Zeszyty Naukowe USz” nr 445, „Prace Katedry Makroekonomii" nr 12, Wydawnictwo USz, Szczecin 2007, s. 158; B. Ciesielski, Wpływ integracji z Unia Europejska na rozwój konkurencji w polskim sektorze usług telekomunikacyjnych, „Zeszyty Naukowe Wyższej Szkoły Zarządzania POU” nr 3(53), Wydawnictwo PRET SA, Warszawa 2011, s. 32-40; obliczenia własne na podstawie raportu UKE za rok 2013.

Oligopolistyczny rynek telefonii mobilnej do 2006 r. zachowywał stabilność w sensie zbliżonych corocznych wartości wskaźnika HHI. Dopiero wejście na rynek w 2007 r. czwartego gracza oraz operatorów MVNO spowodowało spadek wartości tego wskaźnika i jego systematyczne obniżanie w kolejnych latach. Odzwierciedlało to coraz niższą koncentrację rynku i zaostrzenie rywalizacji ${ }^{17}$. Mimo że konkurencja monopolistyczna jest wyższą formą konkurencji rynkowej od oligopolu, to jednak wskaźniki $H H I$ dla segmentu telefonii mobilnej były niższe od tych wskaźników dla

17 B. Ciesielski, op.cit., s. 36 i 37; obliczenia własne na podstawie raportu UKE za rok 2013. 
badanych segmentów telefonii stacjonarnej. Przyczyną takich wyników był nadal dominujący udział rynkowy operatora zasiedziałego (TP SA).

Wdrożenie konkurencji w telekomunikacji jest niezwykle istotne z punktu widzenia realizacji funkcji użyteczności publicznej usług telekomunikacyjnych. Funkcje te są zdecydowanie efektywniej pełnione w warunkach konkurencji niż w monopolu. Operatorzy telekomunikacyjni, którzy funkcjonują w warunkach konkurencyjnego rynku, rywalizują o klienta poprzez obniżkę cen, powodując w ten sposób powszechną dostępność usług telekomunikacyjnych. Konkurencja wymusza również wprowadzanie coraz bardziej zaawansowanych rozwiązań technicznych, które podwyższają jakość oferowanych usług i poszerzają ich ofertę. W szerszym znaczeniu istnienie konkurencji w sektorze telekomunikacji jest podstawą rozwoju i wzrostu konkurencyjności całej gospodarki narodowej.

\section{Dynamika ilościowa segmentu telefonii mobilnej}

Segment telefonii ruchomej charakteryzuje ciągły rozwój. Wskazują na to wartości wskaźników na przedstawionych rysunkach, chociaż nastąpił niewielki spadek przychodów. Poza tym zauważalne jest również spowolnienie wzrostu nasycenia. Tendencje te są zauważalne w ostatnich latach.

Rysunek 1. Penetracja rynku telefonii ruchomej w latach 2002-2013 (w \%)

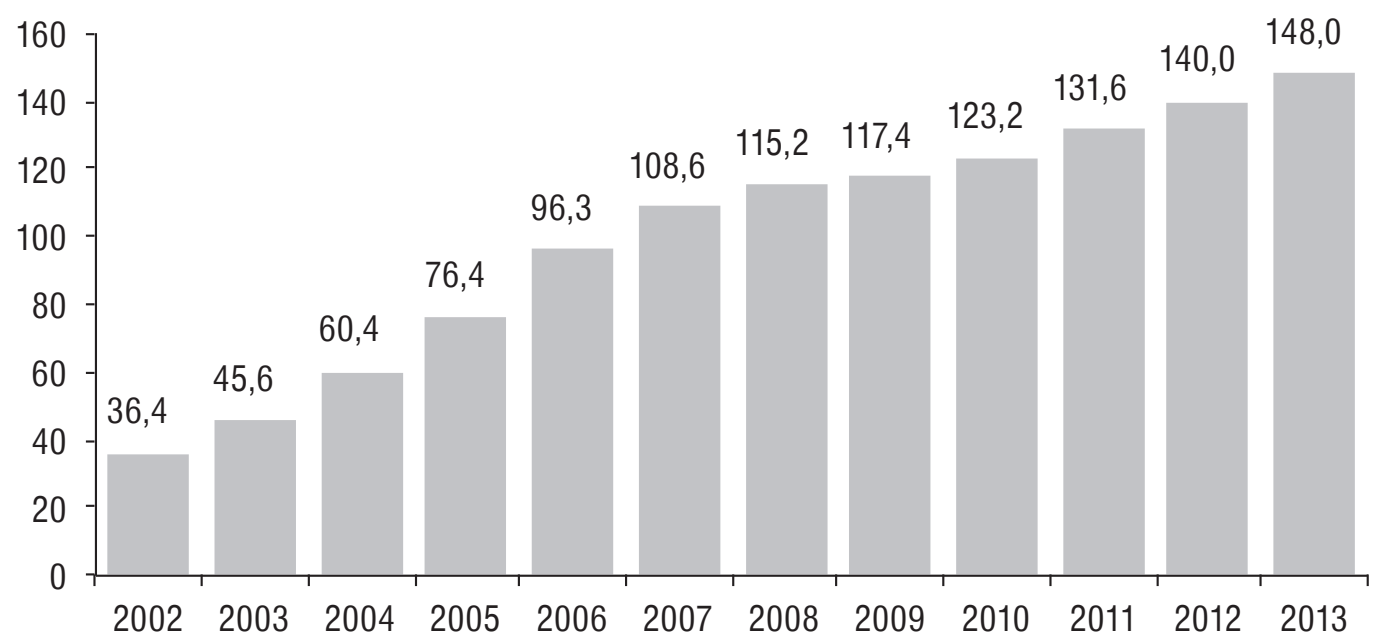

Źródło: Opracowanie własne na podstawie Raportów o stanie rynku telekomunikacyjnego w Polsce w latach 2004-2013, UKE, Departament Strategii i Analiz Rynku Telekomunikacyjnego, Warszawa. 


\section{Rysunek 2. Wartość rynku telefonii ruchomej w latach 2002-2013 (w mln PLN)}

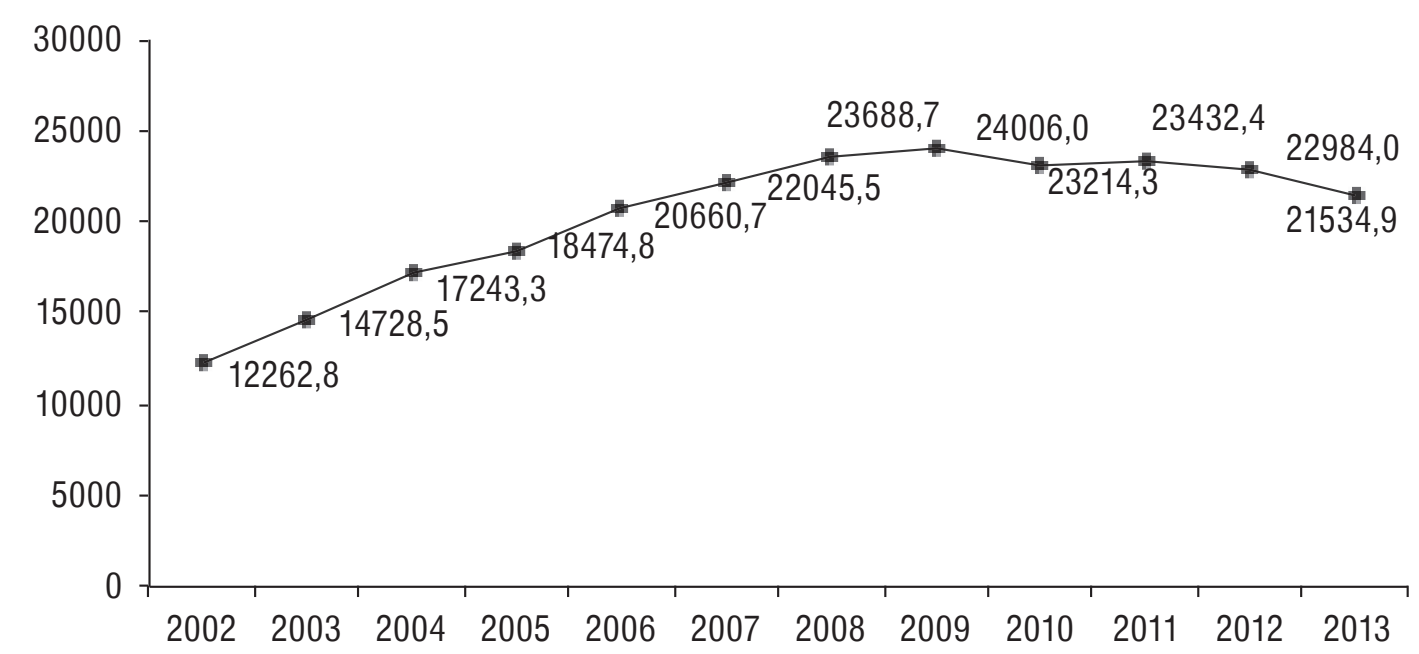

Źródło: Opracowanie własne na podstawie Roczników Statystycznych, Łączność - wyniki działalności z roku: 2003, 2005, 2007, 2009, 2011, 2013, GUS, Departament Handlu i Usług, Warszawa.

Wartości wskaźnika penetracji zaprezentowane na rysunku 1 wyznaczono według formuły:

$$
\frac{\text { liczba kart SIM }}{\text { liczba ludności w Polsce }} \cdot 100 \%
$$

W latach 2002-2013 nastąpił nieco ponad czterokrotny wzrost nasycenia rynku. Wartość wskaźnika (3) w 2013 r. na poziomie 148\% wskazuje na liczbę kart SIM (subscriber identity module) równą $56 \mathrm{mln}$. Obserwowane na kolejnym rysunku spowolnienie wartości obrotów w 2009 r. i spadek w 2010 r. powiązane było m.in. z ogólną koniunkturą gospodarczą $\mathrm{w} \mathrm{kraju}{ }^{18}$. W 2009 r. odnotowano spowolnienie gospodarcze, które rozpoczęło się w połowie 2008 r. Przełożyło się to na aktywność i wyniki przedsiębiorstw oraz na konsumpcję gospodarstw domowych. W kolejnych latach, pomimo nieznacznego ożywienia gospodarczego, wartości obrotów najpierw w 2010 r. nieznacznie spadły, a ich relatywnie niewielki wzrost nastąpił dopiero w 2011 r., po czym znowu obserwowany był niewielki trend spadkowy. Innymi przyczynami tej tendencji była redukcja stawek MTR, obniżki cen połączeń na rynku detalicznym, a zwłaszcza obniżka stawek roamingowych, zarówno na poziomie detalicznym, jak i hurtowym.

\footnotetext{
18 Sytuacja koniunkturalna w Polsce w przywołanym okresie została szeroko opisana w: Koniunktura gospodarcza świata i Polski w latach 2007-2010, red. K. Marczewski, Instytut Badań Rynku, Konsumpcji i Koniunktur, Warszawa 2009, s. 113-130; Koniunktura gospodarcza świata i Polski w latach 2008-2011, red. K. Marczewski, Instytut Badań Rynku, Konsumpcji i Koniunktur, Warszawa 2010, s. 119-135; Koniunktura gospodarcza świata i Polski w latach 2009-2012, red. K. Marczewski, Instytut Badań Rynku, Konsumpcji i Koniunktur, Warszawa 2011, s. 128-145.
} 
W związku z tym w Polsce spada systematycznie wartość średniego miesięcznego przychodu na klienta (average revenue per user, ARPU) w telefonii komórkowej.

$\mathrm{W}$ analizie nasycenia rynku telefonii mobilnej, w której wskaźnik penetracji (3) nie uwzględnia klientów, którzy nie korzystali z usług ponad 3 miesiące, w 2013 r. odnotowano 136,8\%. Była to wartość o 5,9 pkt. proc. powyżej średniej dla krajów Unii (130,9\%). Wyniki tej analizy przedstawiono na rysunku 3.

\section{Rysunek 3. Penetracja rynku telefonii ruchomej w krajach UE w 2013 r. (w \%)}

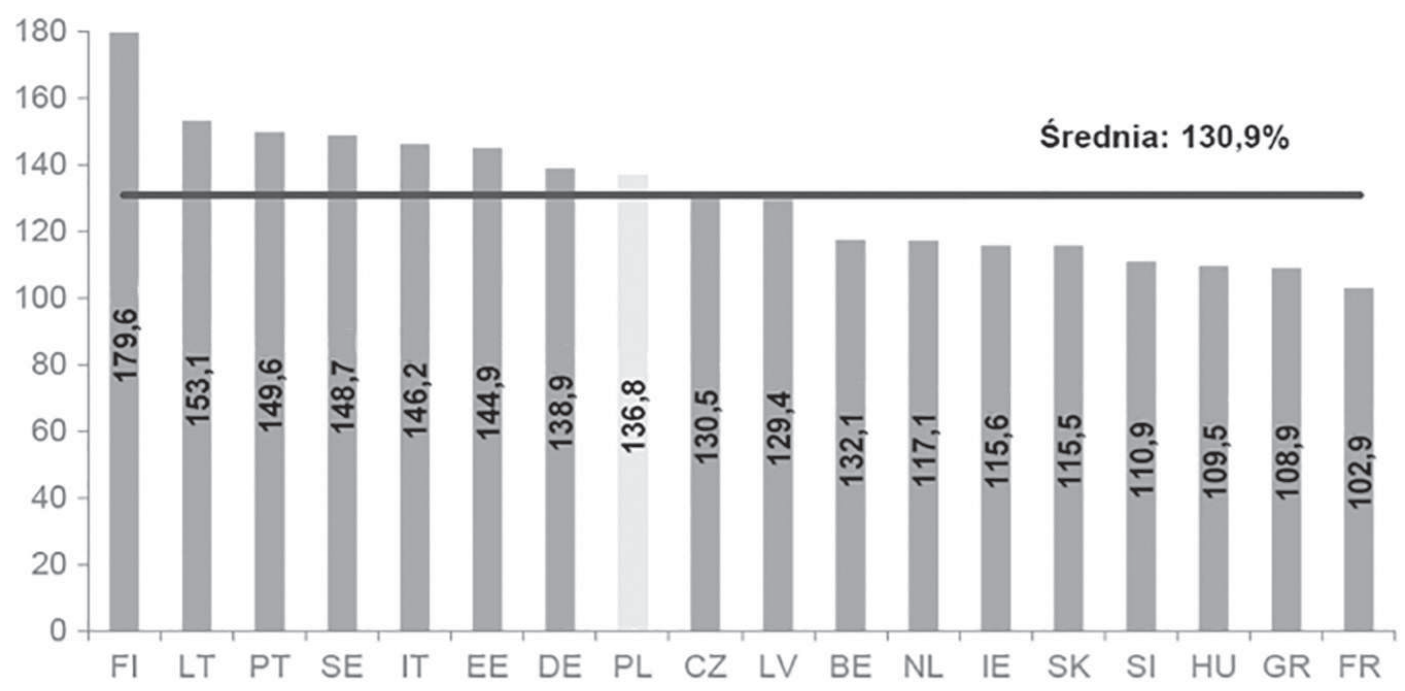

Źródło: Raport o stanie rynku telekomunikacyjnego w Polsce w 2013 roku, UKE, Departament Strategii i Analiz Rynku Telekomunikacyjnego, Warszawa, czerwiec 2014, s. 24.

Dominującą część przychodów (81\%) wygenerowali w 2013 r. klienci post-paid. Ze względu na rodzaj usługi największe przychody pochodziły z połączeń głosowych wychodzących (52,5\%), przychody z transmisji danych osiągnęły 20,8\%, z SMS-ów - 16,5\%, zaś z MMS-ów - 10,2\%. Podobnie jak w poprzednich latach przychody detaliczne z sektora telefonii ruchomej w 2013 r. stanowiły największą część wartości całego rynku telekomunikacyjnego (w 2013 r. prawie 46,3\%).

W okresie lat 2006-2010 z roku na rok spadał udział liczby klientów korzystających z usług pre-paid w strukturze klientów pod względem sposobu płatności za usługi. W 2011 r. doszło do odwrócenia tego trendu i wzrostu udziału użytkowników usług przedpłaconych (rysunek 4). Załamanie trendu zostało pogłębione w 2012 r., kiedy udział abonentów na zasadach pre-paid wzrósł po raz drugi. Natomiast struktura klientów według rodzaju płatności w 2013 r. nie uległa zmianie i kształtowała się następująco: klienci usług abonamentowych stanowili $45,8 \%$, a usług przedpłaconych $54,2 \%$. 


\section{Rysunek 4. Struktura klientów usług abonamentowych i przedpłaconych w latach 2006-2013 (w \%)}

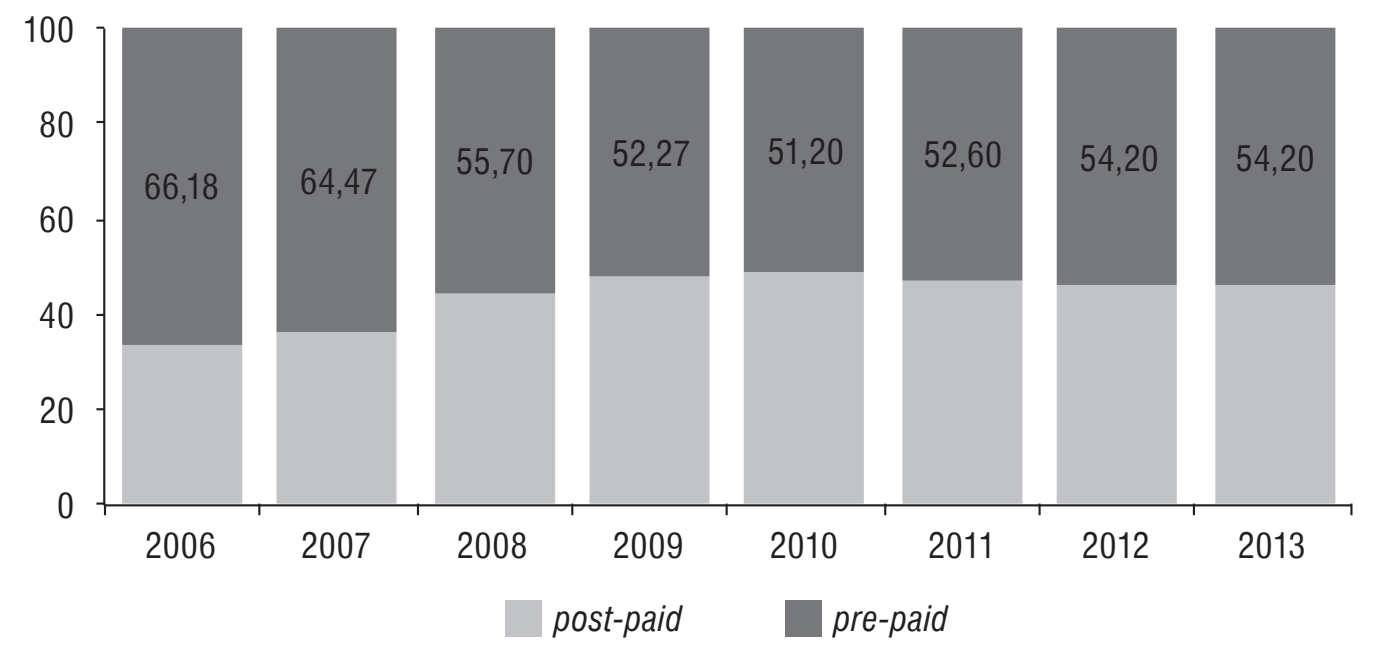

Źródło: Opracowanie własne na podstawie Raportów o stanie rynku telekomunikacyjnego w Polsce w latach 2009-2013, UKE, Departament Strategii i Analiz Rynku Telekomunikacyjnego, Warszawa.

Udziały w rynku największych operatorów są stabilne, przy czym z roku na rok można zauważyć umacnianie pozycji operatora P4. W 2013 r. nastąpiła zmiana operatora wiodącego na rynku telefonii komórkowej w Polsce pod względem osiągniętych przychodów. Został nim Polkomtel (w miejsce Orange Polska), uzyskując 30,2\%. Swoją pozycję o 3 pkt. proc. poprawił operator sieci Play. Analiza udziałów rynkowych prowadzi do wniosku, że badany rynek nadal jest podzielony prawie w równym stopniu na trzy firmy (obecnie: Orange Polska, Polkomtel, T-Mobile), tworząc tripol. Ze względu jednak na rosnącą pozycję operatora P4 wydaje się, że rynek ten będzie miał formę oligopolu złożonego z czterech „graczy”. Analiza udziałów rynkowych prowadzi do wniosku, że mechanizm regulacyjny oparty na udostępnieniu zasobów operatorom wirtualnym słabo sprawdził się w warunkach nasyconego już rynku telefonii mobilnej. Udziały operatorów pod względem przychodów zaprezentowano na rysunku 5.

W roku 2013 użytkownik telefonii ruchomej rozmawiał średnio rocznie przez ponad 1966 minut. W tej kwestii w latach 2002-2013 obserwowany był systematyczny wzrost, co było efektem spadku cen. Średnia liczba minut połączeń głosowych na jednego użytkownika w Polsce w 2013 r. według przyjętego przy penetracji kryterium aktywności wyniosła 1420 minut. Uplasowało to Polskę poniżej średniej dla krajów UE, która wyniosła 1657 minut (rysunek 6). 
Rysunek 5. Udziały operatorów pod względem przychodów w 2013 r. (w \%)
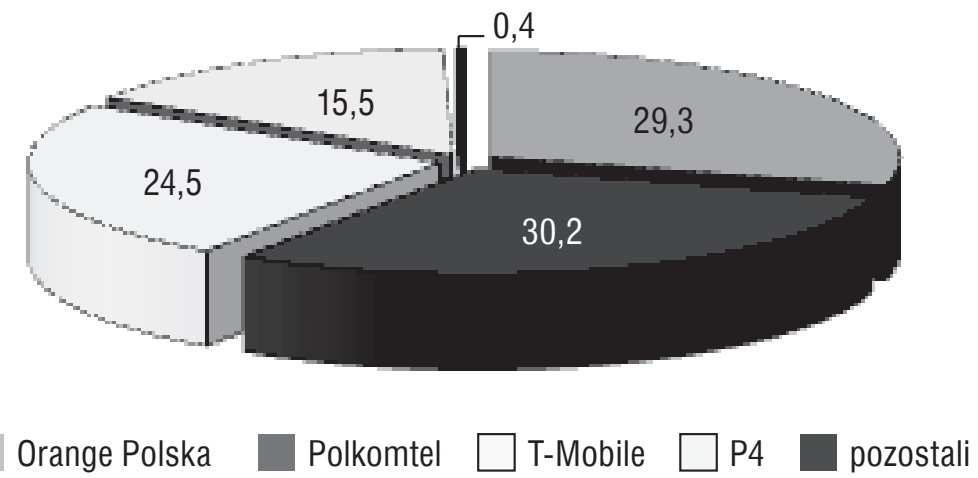

Źródło: Opracowanie własne na podstawie Raportu o stanie rynku telekomunikacyjnego w Polsce w 2013 roku, UKE, Departament Strategii i Analiz Rynku Telekomunikacyjnego, Warszawa, czerwiec 2014, s. 26.

Rysunek 6. Czas połączeń głosowych wychodzących w krajach UE na jednego aktywnego użytkownika w 2013 r. (w min)

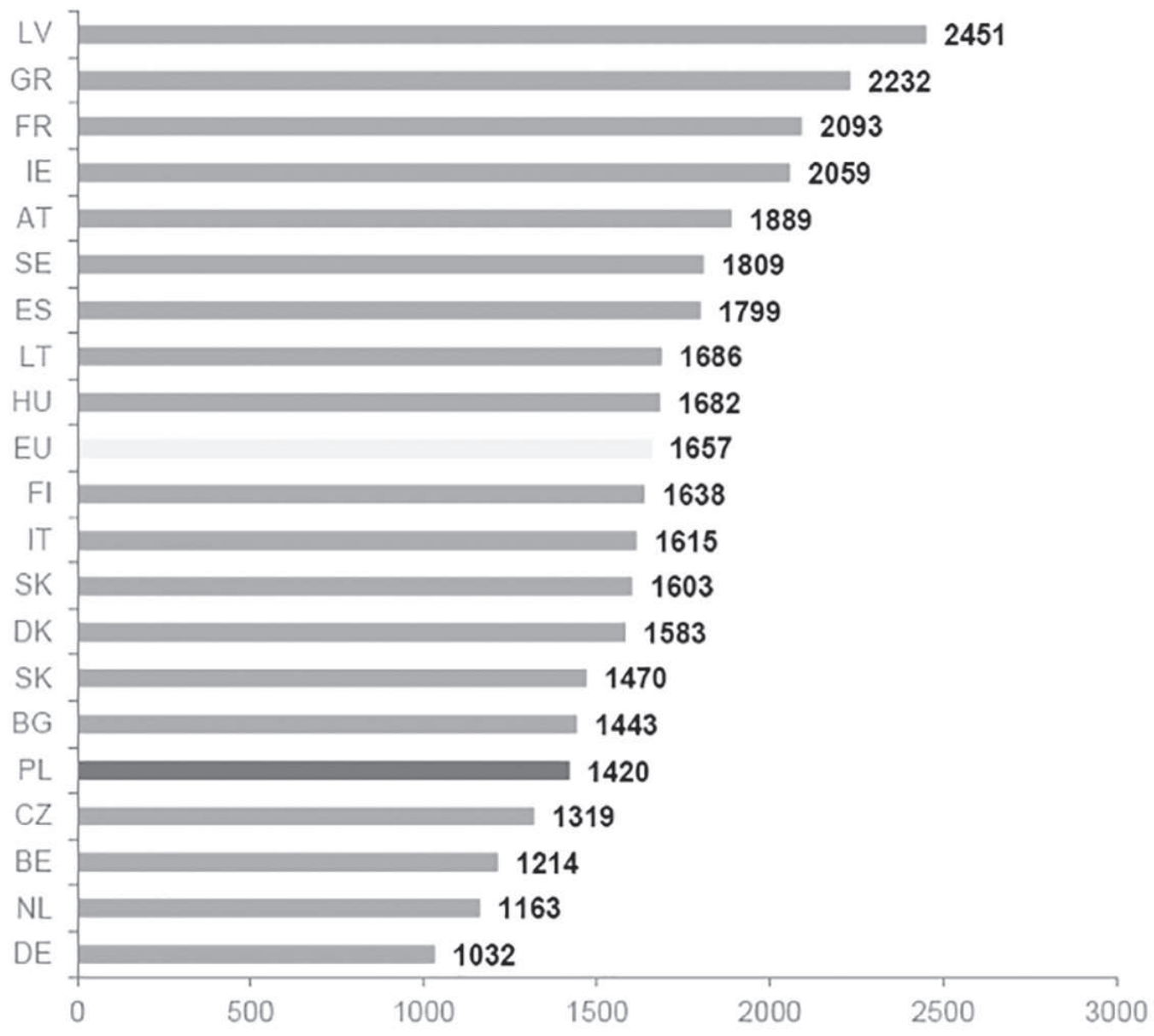

Źródło: Raport o stanie rynku telekomunikacyjnego w Polsce w 2013 roku, op.cit., s. 28. 
Według stanu na 31 grudnia 2013 r. na rynku telefonii ruchomej działalność prowadziło 26 przedsiębiorców telekomunikacyjnych, w tym 19 operatorów sieci wirtualnych (MVNO). Liczba operatorów telefonii mobilnej w badanych latach charakteryzowała się trendem wzrostowym.

\section{Podsumowanie}

W opracowaniu potwierdzono tezę o wielokrotnym wzroście zapotrzebowania na usługi telefonii mobilnej w okresie lat 2002-2013, o czym świadczy rosnąca wartość wskaźnika nasycenia rynku i wzrostowy trend średniego rocznego czasu połączeń abonenta.

Ze względu na wysokie nasycenie rynku wzrost liczby aktywnych kart SIM w najbliższych latach jedynie w minimalnym stopniu zależeć będzie od zupełnie nowych użytkowników. Wzrost penetracji rynku będzie oparty na klientach posiadających więcej niż jeden telefon. Jest to również segment rynku generujący największe przychody ze wszystkich segmentów rynku telekomunikacyjnego.

Rynek telekomunikacji mobilnej ma formę oligopolu złożonego z trzech podmiotów, ale w przyszłości może być podzielony na cztery podmioty. Ważne okazało się zatem wprowadzenie czwartego "gracza” (P4) wykorzystującego własną sieć komórkową. Wprowadzenie operatorów MVNO nie skutkowało zajęciem przez ten typ podmiotów liczącej się pozycji w strukturze rynku.

Utworzenie w 1995 r. w segmencie telefonii mobilnej modelu oligopolistycznego było wprawdzie na tle innych segmentów niewątpliwym sukcesem, ale obecnie jest to model rynku, w którym zakłada się niższy (w porównaniu z dominującym już modelem konkurencji monopolistycznej) rozwój konkurencji. Wskaźniki koncentracji rynku są jednak w segmencie telefonii mobilnej niższe (korzystniejsze) niż dla segmentów telefonii stacjonarnej ze względu na prawie równe i nieobejmujące całości przychodów udziały głównych "graczy”. Biorąc pod uwagę nasycenie rynku, obroty i stopień koncentracji, rozwój rynku telefonii mobilnej w Polsce można ocenić pozytywnie.

Wprowadzenie konkurencji było $\mathrm{w}$ analizowanym segmencie najprostsze pod względem prawnym i technicznym, ponieważ rynek zaczął kształtować się w Polsce dopiero w latach 90. XX w. i nie bazował na istniejącej już infrastrukturze telekomunikacyjnej. 


\section{The Development analysis of Polish mobile telephony market between 2002-2013}

The purpose of this article is to analyze the changes and current state of the Polish mobile telephony market. The thesis of the article states that a multiple increase in demand for telecommunication services has been observed on the Polish mobile telephony market in 2002-2013. The article describes the transformation of the Polish mobile telephony market based on its demonopolization and liberalisation. The quantitative research was based on the annual statistical data of Central Statistical Office and reports of Office of Electronic Communications.

Keywords: mobile telephony market, demonopolization, liberalisation, oligopoly, market saturation, telecom operator, value of market, average revenue per user

\section{L'analyse du développement de marché polonais de la téléphonie mobile entre 2002 et 2013}

Le but de cet article est d'analyser les changements et l'état actuel du marché polonais de la téléphonie mobile. La thèse de l'article précise qu'une augmentation multiple dans la demande de services de télécommunication a été observée sur le marché polonais de la téléphonie mobile entre 2002 et 2013. L'article décrit la transformation du marché de la téléphonie mobile polonais en fonction de sa démonopolisation et sa libéralisation. Une recherche quantitative a été basée sur les données statistiques annuelles du Bureau central des statistiques de Pologne et les rapports de l'Office des communications électroniques en Pologne.

Mots-clés: le marché de la téléphonie mobile, la démonopolisation, la libéralisation, l'oligopole, la saturation du marché, l'opérateur de télécommunications, la valeur du marché, le revenu moyen par utilisateur 


\section{Анализ развития польского рынка мобильной телефонной связи B 2002-2013 гr.}

Цельюнастоящей статьи является анализ изменений на польском рынке мобильной телефонной связи и его текущее состояние. В работе подтверждается тезис о большом росте спроса на телекоммуникационные услуги на польском рынке мобильной телефонии в 2002-2013 гг. Описываютсяизменения рынка мобильной телефонии,основой которых стали демонополизация и либерализация. Для количественных исследований были использованы ежегодныеданные Центрального бюро статистики (GUS) Польши и рапорты Управления электронных коммуникаций (UKE).

Ключевые слова: рынок мобильной телефонии, демонополизация, либерализация, олигополия, насыщенность рынка, оператор связи, рыночная стоимость, средняя ежемесячная выручка на одного абонента 